\title{
Do schools in Quebec foster healthy eating? An overview of associations between school food environment and socio-economic characteristics
}

\author{
Pascale Morin ${ }^{1, *}$, Karine Demers ${ }^{1}$, Éric Robitaille ${ }^{2}$, Alexandre Lebel $^{3}$ and Sherri Bisset ${ }^{3}$ \\ ${ }^{1}$ Faculty of Physical and Sport Education, University of Sherbrooke, 2500 boulevard de l'Université, Sherbrooke, \\ Québec, Canada, JIK 2R 1: ${ }^{2}$ Quebec's National Institute of Public Health, Montréal, Québec, Canada: ${ }^{3}$ Evaluation \\ Platform on Obesity Prevention, Québec, Québec, Canada
}

Submitted 2 November 2013: Final revision received 20 August 2014: Accepted 28 November 2014: First published online 16 January 2015

\begin{abstract}
Objective: A school environment that encourages students to opt for food with sound nutritional value is both essential and formative in ensuring that young people adopt healthy eating habits. The present study explored the associations between the socio-economic characteristics of the school environment and the school food environment.

Design: A cross-sectional survey was conducted in 2008-2009. Descriptive and bivariate analyses were performed on data from public primary and secondary schools.

Setting: Quebec, Canada. The school food offering was observed directly and systematically by trained research assistants. Interviews were conducted to fully describe food offerings in the schools and schools' child-care services.

Subjects: A two-stage stratified sampling was used to build a representative sample of 143 French-speaking public schools. The response rate was $66 \cdot 2 \%$.

Results: The primary and secondary schools in low-density areas were more likely to be located near diners (primary: $P=0.018$; secondary: $P=0 \cdot 007$ ). The secondary schools in deprived areas were less likely to have a regular food committee $(P=0.004)$, to seek student input on menu choices $(P=0 \cdot 001)$ or to have a long lunch period $(P=0 \cdot 010)$. The primary schools in deprived areas were less likely to have a food service $(P=0.025)$ and their meal periods were shorter $(P=0.033)$.

Conclusions: The schools in areas with lower socio-economic status provided an environment less favourable for a healthy diet. From a public health perspective, the results of this analysis could assist policy makers and managers to identify actions to support the creation of favourable school environments.
\end{abstract}

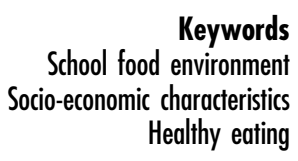

In Canada, $32 \cdot 0 \%$ of children aged 5 to 17 years were overweight between 2009 and $2011^{(1)}$. The school setting is recognized as providing a unique opportunity to expose all children to an environment that offers healthy foods, promotes regular physical activity and translates lifelong skills for healthy eating and active living ${ }^{(2-4)}$. Indeed, Briefel et al. ${ }^{(5)}$ estimated that secondary-school students get $26 \%$ of their energy from foods consumed at school. Schools can also influence families and the community through their health-promotion interventions ${ }^{(4)}$. Consequently, by modifying aspects of the school food environment such as food offerings and dining areas, health-promotion strategies have the potential to enhance individual behaviours ${ }^{(6)}$.

In 2007, the provincial government of Quebec (Canada) disseminated a three-part Framework Policy guiding school-based strategies to promote healthy weights ${ }^{(7)}$. The first component follows recommendations from Canada's Food Guide ${ }^{(8)}$ and advocates, among other things, low-fat dishes; fruit-based desserts and snacks; whole-grain products; and $100 \%$ pure juices, in addition to milk and water. The second component suggests eliminating foods of low nutritional value, such as fried foods and sweetened beverages, from all school food offerings. The third component addresses the provision of appropriate areas and conditions for eating meals.

Studies pertaining to school food environments have dealt primarily with policy implementation ${ }^{(9-11)}$ and the quality of food offerings in ${ }^{(12)}$ and around the school ${ }^{(13-15)}$. Research has also revealed associations between the school food environment and school size, population density and 
neighbourhood characteristics. For example, school size has been found to influence the diversity of food offerings healthy or otherwise - since catering profitability is tied to sales $^{(16)}$. Large schools may also have larger budgets, enabling them to implement measures to develop a more favourable food environment. The population density around schools also appears to influence the school food environment; a Canadian study found that relative to urban schools, schools in small towns and rural areas had poorer food environments and higher prevalence rates of overweight ${ }^{(17)}$. Indirect evidence suggests a possible association between the socio-economic status of the school and the school food environment. Namely, the density of fast-food restaurants around schools positively associates with students' $\mathrm{BMI}^{(18,19)}$ and inversely associates with neighbourhood income ${ }^{(14,15,18,19)}$. To the best of our knowledge, no study has directly addressed the relationship between the socio-economic status of the school, measured by family income of neighbourhood residents with children under 18 years of age, and the school food environment. Our research thus responds to this lacuna by asking if school characteristics measured by the low-income index, size (total number of students) and the population density are associate with the school food environment.

\section{Methods}

\section{Conceptual model}

Drawing inspiration from the Quebec Framework as well as Cohen's structural model of health behaviours at the population level ${ }^{(6,7,20)}$, we developed a conceptual model for the school food environment comprising five environmental components as shown in Fig. 1.

Among the school environment components in the righthand side of Fig. 1, the availability of healthy food offerings can create social norms based upon healthy diet and, in so doing, positively influence students' attitudes and beliefs. Physical structures include the availability and access to specified eating areas as well as the physical layout of these areas. Policy and organizational structures are described by working procedures, roles and routines that concern food services and resources. Economic structures refer specifically to the rules that guide the selection of resources as a function of budget. Educational and promotional activities refer to the circulation of educational materials and information in the school regarding healthy eating.

\section{Study population}

We conducted a cross-sectional survey of food offerings and physical activity in Quebec schools between October 2008 and March 2009. Small schools (primary, fewer than forty students; secondary, $<100$ students), vocationaltraining centres, Aboriginal schools and private vocational schools (e.g. for disabled students) were excluded in order to ensure that the sample was homogeneous with respect food availability and physical activities. Moreover, English-language schools and remote schools (i.e. hard to reach by car or located more than $250 \mathrm{~km}$ from each other) were excluded for financial reasons. The study was conducted according to the guidelines laid down in the Declaration of Helsinki and all procedures involving human subjects were approved by the research ethics committee of the Estrie Health and Social Services Centres (CER \# 08-005).

\section{Sampling frame}

In order to produce a reliable and representative sample of schools in the province of Quebec, we used a two-stage stratified sampling technique. For the first sampling stage, eleven out of the seventeen administrative regions were selected. This included the four most populated metropolitan regions in Quebec, a random selection of
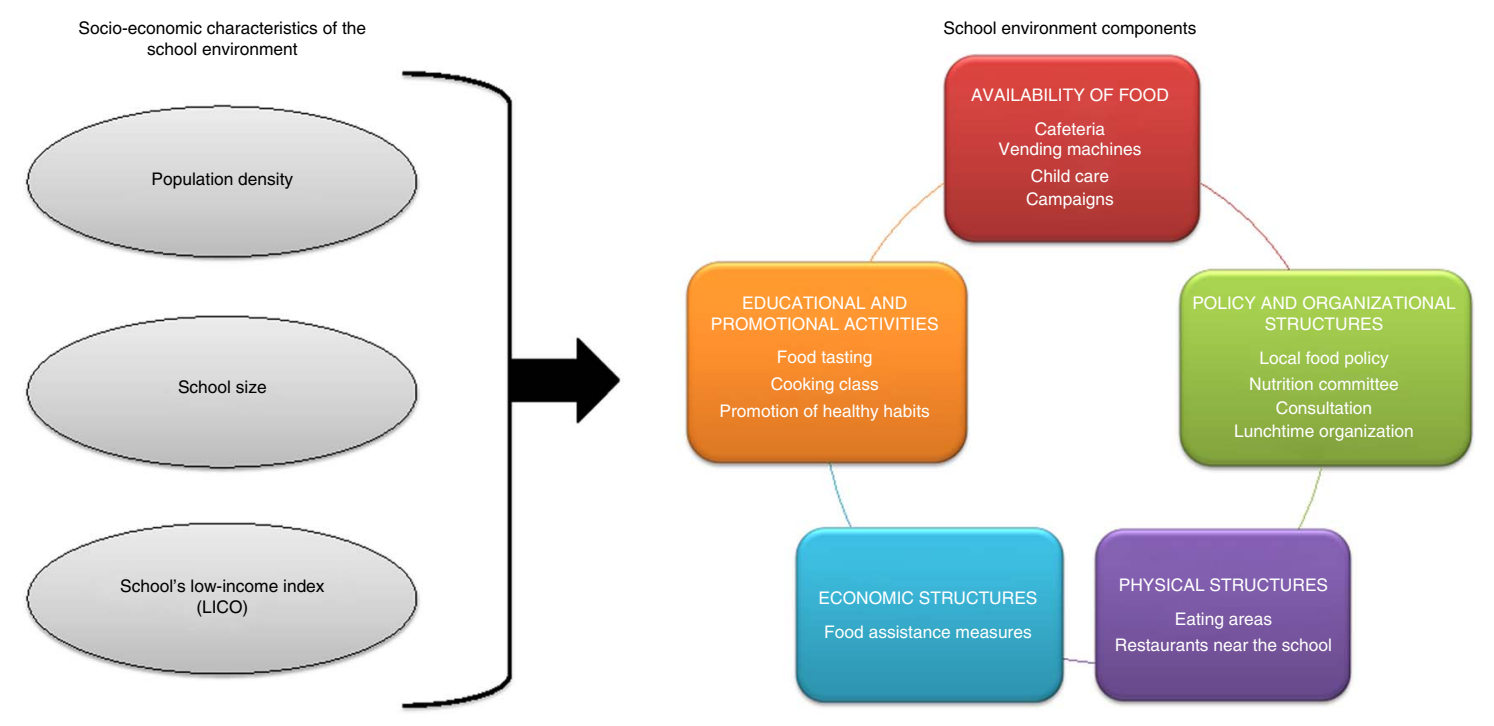

Fig. 1 (colour online) Conceptualization of the school food environment (LICO, low-income cut-off) 


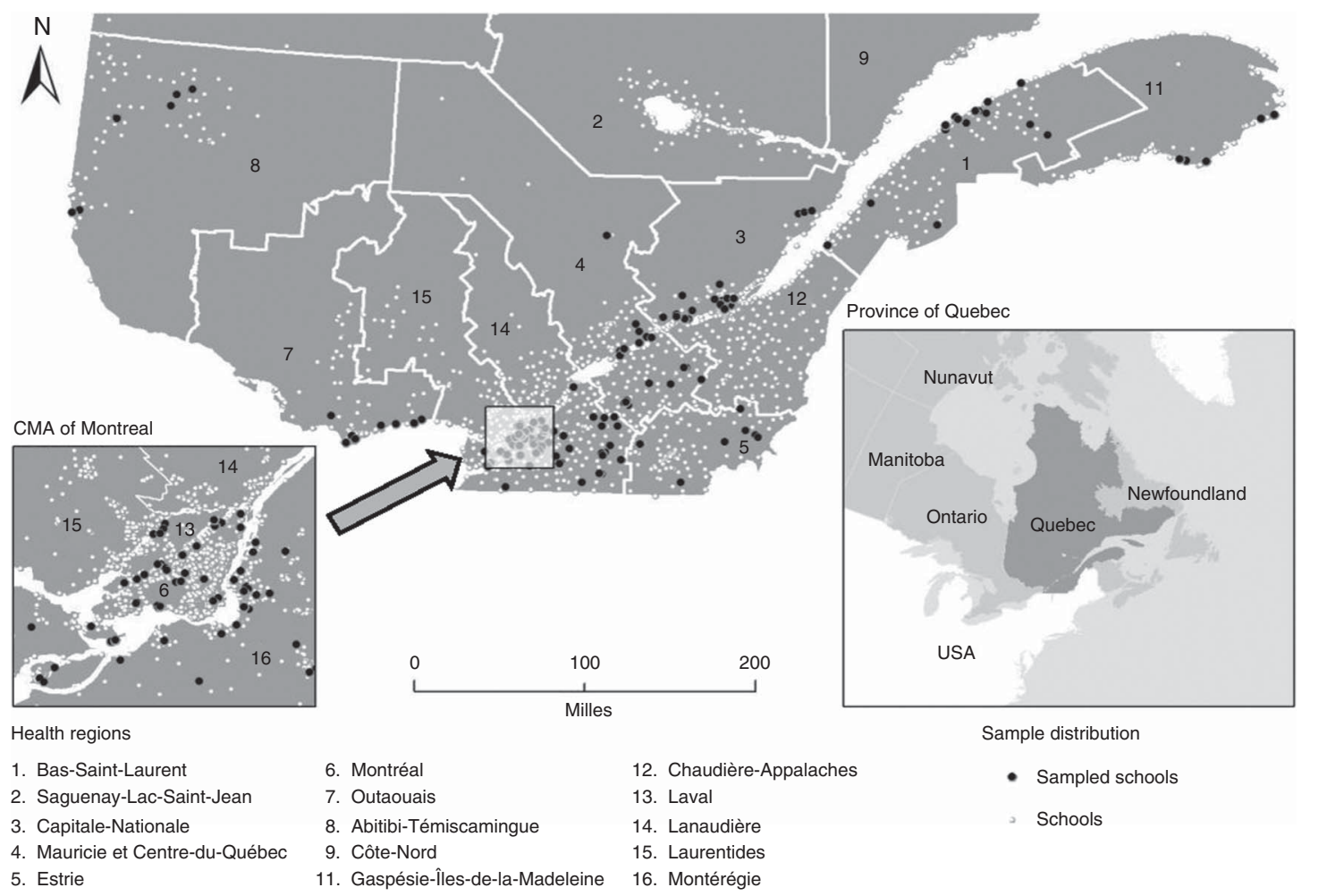

Fig. 2 Geographic location of the target schools (CMA, census metropolitan area)

five out of the nine regions located within $100 \mathrm{~km}$ from the selected metropolitan regions, and two of the three remote regions (beyond $100 \mathrm{~km}$ from the selected metropolitan regions). For the second sampling stage, the number of schools randomly selected per region was proportional to the number of schools in each of the eleven administrative regions. The initial sample comprised 216 schools (Fig. 2). Schools were recruited through direct telephone calls and emails to the school board directorate and the principal. Letters explaining the aims of the study, the benefits and inconveniences were thus provided to all schools invited to participate in our study.

\section{Data-collection procedure}

Registered dietitians and nutrition technicians received four days of training during which time the procedures and techniques to follow during data collection were taught and practised. This assured stability in how data collection was completed to avoid subjective assessments. Data were collected during a full day and included observations and questionnaires. Questionnaires were completed with school principals, food-service managers and child-care service managers and queried the food environment within the school. Observation checklists recorded all foods available to students in the cafeteria, vending machines and child-care service. Observations also documented meal contexts. The observation checklist and questionnaire were validated beforehand by a committee of experts and then pre-tested in forty-two Quebec schools. Table 1 presents the number of completed questionnaires for each data-collection strategy.

\section{Measures}

\section{School food environments}

The observation checklist, based on the work of Oldenburg et al. ${ }^{(21)}$, Quebec studies ${ }^{(22,23)}$ and the Framework Policy ${ }^{(7)}$, recorded all foods and beverages offered to students for lunch on cafeteria service lines on the day of the visit, in the vending machines and in the child-care service. Foods were recorded dichotomously on the checklist (available or not; yes/no). Given that a school can offer both foods of high and low nutritional value, two indices were created according to the Canadian Food Guide which served to define these food groups and their serving sizes. The index of favourable food offerings in the cafeteria' was defined based on the availability (yes/no) of the following four food groups: (i) milk or enriched soya beverages; (ii) vegetables/fruit in the dishes on the daily menu as a whole or as side dishes; (iii) an adequate serving of protein in the dishes on the daily menu as a whole or in at least one à la carte dish on the menu; and (iv) an adequate serving of whole-grain products or potatoes in the dishes on the menu. The 'index of unfavourable food offerings' refers to the availability of at least one of: (i) beverages containing added sugar, sweetener or caffeine; (ii) foods high in fat, sugar or containing sweeteners; (iii) fried foods; or (iv) deli meats (see Appendix). Vending machines with at least $75 \%$ 
Table 1 Data-collection strategies for each institution type*

\begin{tabular}{lcc}
\hline & Primary schools $(n)$ & Secondary schools $(n)$ \\
\hline Interview with school management & 77 & 66 \\
Interview with the food-service manager & 50 & 66 \\
Interview with the child-care service manager & 69 & $\mathrm{~N} / \mathrm{A}$ \\
Observation of food offerings in the cafeteria & 49 & 66 \\
Observation of food offerings in vending machines & $\mathrm{N} / \mathrm{A}$ & 47 \\
Observation of food offerings in the child-care service & 48 & $\mathrm{~N} / \mathrm{A}$ \\
Observation of the context at mealtimes & 74 & 66 \\
\hline
\end{tabular}

N/A, not applicable.

*Schools that did not have food services were not surveyed.

foods/beverages of good nutritional value met the criterion for a healthy food offering.

The foods and beverages sold during school-related activities (fundraising campaigns, special events, tastings, cooking activities) were inventoried on a checklist consisting of fifteen food categories based on the Appendix. For example, the foods and beverages of low nutritional value ( $n$ 7) corresponded to beverages with added sugar, pastries and other foods high in fat or sugar and salty snack foods; and the foods and beverages of high nutritional value ( $n$ 8) corresponded to fruits and vegetables, pure fruit juice and dishes with sufficient protein.

The four remaining school food environment components pertaining to school policy and organizational, physical, economic structures, as well as school educational and promotional activities were obtained through a questionnaire completed as part of an interview. Principals, child-care managers and food-service managers, in accordance with their respective roles, provided information regarding the type of menu served, the presence of food outlets within a 10 min walk from the school, assistance measures, foods sold or consumed during schoolrelated activities and foods eaten during activities at the child-care service.

\section{Socio-economic and demographic characteristics} of the school

Three socio-economic and demographic characteristics of the school environment were measured by: (i) population density; (ii) school size; and (iii) low-income index (Fig. 1). Population density was determined by dividing the number of inhabitants in each municipality containing a participating school by the municipality's area (in square kilometres). Number of inhabitants and school size are collected regularly by the Quebec government ${ }^{(24,25)}$. Data used to create the low-income index come from the Canadian census at the dissemination area level (a dissemination area comprises an average of 700 individuals). The low-income cut-off (LICO) indicates the proportion of families with children aged between 0 and 18 years living under the low-income threshold, within all dissemination areas for which there is at least one student registered to that specific school ${ }^{(26)}$. The LICO is calculated for each school and schools are scored from 1 (most privileged) to 10 (most deprived).

\section{Statistical analysis}

The analyses were performed separately for primary and secondary schools using the statistical software package IBM SPSS Statistics version 19.0. Given the skewed data distribution, the median and interquartile ranges (IQR) were used. The characteristics of the primary and secondary schools were compared using the Mann-Whitney $U$ test, which is used to compare two samples that are small or have skewed distributions. Descriptive analyses were also carried out for each of the five school food environmental components. We used Spearman's rho and the Mann-Whitney $U$ test to check for associations between school environmental components and the socioeconomic characteristics of the school environment instead of their parametric counterparts. Spearman's rho is suitable for assessing correlations between two continuous variables with skewed distributions. The data in the study were weighted to take into account the real proportion of public primary and secondary schools in each administrative region included in the study. The weighting also included a post-stratification factor to ensure the representativeness of the student samples with respect to the study population. A threshold of significance of $95 \%$ was used to interpret the statistical significance of probability tests, corresponding to a $P$ value of $<0 \cdot 05$.

\section{Results}

A total of 143 schools took part in the study (seventy-seven primary and sixty-six secondary). Table 2 provides the schools' characteristics. This sample corresponds to a $66.2 \%$ response rate. A total of sixty schools declined to participate in the study, nine could not be contacted and four were excluded because they did not meet the selection criteria. No significant differences were observed between the participating and non-participating schools in terms of school size $(U=5053 \cdot 5, P=0 \cdot 702)$. Significantly fewer schools with more deprived families (LICO, $U=3853.0, P=0.002$ ) and fewer schools located in densely populated areas ( $U=3422 \cdot 5, P<0 \cdot 001$ ) took part in the study. 
Table 2 Characteristics* of primary and secondary schools surveyed, Quebec, Canada, 2008-2009

\begin{tabular}{|c|c|c|c|c|}
\hline & \multicolumn{2}{|c|}{ Primary schools } & \multicolumn{2}{|c|}{ Secondary schools } \\
\hline & Median & IQR & Median & IQR \\
\hline $\begin{array}{l}\text { Population density (habitants } / \mathrm{km}^{2} \text { ) } \\
\text { School size } \\
\text { LICO (2008-2009) } \\
\text { Proportion of students having lunch at school (\%) } \\
\text { Number of meal periods }\end{array}$ & $\begin{array}{r}287 \cdot 0 \\
230 \cdot 0 \\
5 \cdot 0 \\
75 \cdot 0 \\
2 \cdot 0\end{array}$ & $\begin{array}{r}742 \cdot 0 \\
161 \cdot 0 \\
4 \cdot 0 \\
38 \cdot 0 \\
1 \cdot 0\end{array}$ & $\begin{array}{r}295.0 \\
875.0 \\
5.0 \\
69.0 \\
1.0\end{array}$ & $\begin{array}{r}1020 \cdot 0 \\
763 \cdot 0 \\
5 \cdot 0 \\
35 \cdot 0 \\
0.0\end{array}$ \\
\hline & $r_{\mathrm{s}}$ & $P$ & $r_{\mathrm{s}}$ & $P$ \\
\hline $\begin{array}{l}\text { Population density } \times \text { School size } \\
\text { Population density } \times \text { LICO } \\
\text { School size } \times \text { LICO }\end{array}$ & $\begin{array}{r}0.593 \\
0.306 \\
-0.090\end{array}$ & $\begin{array}{r}<0.001 \\
0.002 \\
0.429\end{array}$ & $\begin{array}{l}0.578 \\
0.621 \\
0.265\end{array}$ & $\begin{array}{r}<0.001 \\
<0.001 \\
0.027\end{array}$ \\
\hline
\end{tabular}

IQR, interquartile range; LICO, low-income cut-off; $r_{\mathrm{s}}$, Spearman's rho.

*Weighted data.

\section{School food environments}

Based on the index of favourable food offerings in the cafeteria, $42.2 \%$ of the secondary- and $5.1 \%$ of the primary-school cafeterias offered an adequate serving size for each of the four food groups (Table 3). A high proportion of secondary schools offered sugar-sweetened beverages $(69.0 \%)$ and foods high in fat, sugar or containing sweeteners $(85.8 \%)$. Vending machines offering foods/beverages of high nutritional value (i.e. at least $75 \%$ of the contents) were found in just one out of four high schools. At the child-care service, the median number of foods of good nutritional value was 5 (IQR 4).

In terms of policy and organization, practically none of the elementary schools called upon the services of a registered dietitian to plan their menus $(2.9 \%)$ or involved students on food committees (6.6\%). The secondary schools as a whole offered lunchtime meal service and about half had a regular food committee (52.9\%). Students in primary and secondary schools were respectively provided a median of 33 (IQR 14) $\mathrm{min}$ and 65 (IQR 16) min to eat lunch.

The food outlets found most often in the vicinity (i.e. 10 min walk) of the participating schools were convenience stores, service stations and pharmacies. The food assistance programme most frequently implemented in primary schools $(21.2 \%)$ provided snacks during the school day, whereas secondary schools most often distributed tickets to purchase meals (42.8\%). The median price of the daily menu was CAN\$ 4.00 in both the primary (IQR CAN\$ 0.54) and secondary (IQR CAN\$ 0.88) schools.

The foods and beverages offered during fundraising campaigns had low nutritional value in $54.9 \%$ of the primary schools and in $73.9 \%$ of the secondary schools. At the child-care services, cooking and culinary activities were more popular $(61.0 \%)$ than food tastings $(12.8 \%)$ as educational and promotional activities. The majority of child-care services offered foods and beverages of low nutritional value on special occasions and during cooking activities (respectively, 94.9\% and 68.2\%).

\section{School socio-economic and demographic} characteristics and school food environments

Table 4 summarizes the correlates of school environmental components.

\section{Primary schools}

Low income index. Overall, the LICO of a school was not associated with the availability of foods with high nutritional value. Schools offering foods and beverages of good nutritional value during child-care services were located in more disadvantaged and high-density areas.

In terms of the political and organizational structures, LICO schools were less likely to offer students food services and more likely to provide shorter lunch periods. These schools also had a greater probability of being surrounded by fast-food restaurants and businesses such as dairy bars. They also offered more food assistance programmes, snacks and 'emergency' foods during childcare services. Furthermore, child-care services in LICO schools tended to offer foods and beverages of low nutritional value at special events and during cooking activities. The socio-economic characteristics of the school environment were not associated with the quality of food offerings during fundraising campaigns, tastings organized at the school or for holidays.

School size. The availability of foods with high nutritional value was not associated with the demographic characteristics of the school. The size of the school was, however, significantly associated with the existence of food services; larger schools were more likely to offer food services. Schools having more tastings and cooking activities in their child-care services tended to be larger.

Population density. Overall, schools situated in more densely populated areas were exposed to fewer diners (food outlets) and grocery stores/supermarkets, but to more businesses such as dairy and candy bars. Additionally, such schools were less likely to have a cafeteria with access to functioning drinking fountains or sinks. Schools offering their students breakfast as a food assistance 
Table 3 Descriptive statistics ${ }^{*} \dagger$ related to school environmental components in the primary and secondary schools surveyed, Quebec, Canada, 2008-2009

\begin{tabular}{|c|c|c|c|c|c|c|}
\hline & \multicolumn{3}{|c|}{ Primary schools } & \multicolumn{3}{|c|}{ Secondary schools } \\
\hline & $n$ & $\%$ & $95 \% \mathrm{Cl}$ & $n$ & $\%$ & $95 \% \mathrm{Cl}$ \\
\hline \multicolumn{7}{|l|}{ Availability of food } \\
\hline \multicolumn{7}{|l|}{ Food offerings in cafeterias } \\
\hline \multicolumn{7}{|l|}{ Index of a healthy food environment } \\
\hline Milk and soya drinks & 43 & 87.1 & $75.42,94.64$ & 65 & $100 \cdot 0$ & _ \\
\hline Vegetables and fruit & 4 & 8.9 & $6.67,11.58$ & 35 & 53.8 & $44 \cdot 84,62 \cdot 76$ \\
\hline Protein source & 44 & 88.6 & $77.08,95.69$ & 64 & $97 \cdot 2$ & $89.52,99.80$ \\
\hline Whole-grain products & 24 & 47.6 & $38.05,57.15$ & 50 & $77 \cdot \overline{6}$ & $67.13,86.03$ \\
\hline Presence of the four food groups & 3 & $5 \cdot 1$ & $3.81,6.67$ & 28 & $42 \cdot 2$ & $34.46,49.94$ \\
\hline \multicolumn{7}{|l|}{ Index of an unfavourable food environment } \\
\hline Beverages that are sweet or sweetened or that contain caffeine & 6 & $11 \cdot 2$ & $8.43,14.50$ & 46 & $69 \cdot 0$ & $59.73,78.27$ \\
\hline Food high in fat, suga or sweeteners (including stuffed pastry) & 8 & $15 \cdot 2$ & $11.50,19.54$ & 57 & 85.8 & $75.84,92.82$ \\
\hline Fried foods & 4 & $7 \cdot \overline{6}$ & $5.69,9.90$ & 8 & 12.5 & $9.80,15.63$ \\
\hline Deli meats & 7 & 13.3 & $10.03,17.16$ & 24 & 37.0 & $29.91,44.09$ \\
\hline Presence of at least one type of unfavourable food & 18 & 37.4 & $29.03,45 \cdot 77$ & 62 & 94.6 & $86 \cdot 18,98.68$ \\
\hline \multicolumn{7}{|l|}{ Food offerings in vending machines located near or in dining halls } \\
\hline At least $75 \%$ of contents of good nutritional value & \multicolumn{3}{|r|}{$\mathrm{N} / \mathrm{A}$} & 9 & $25 \cdot 7$ & $18.78,33.65$ \\
\hline Food offerings at the child-care service & & & & & & \\
\hline Presence of at least one food or beverage of low nutritional value & 17 & $37 \cdot 1$ & $28 \cdot 69,45 \cdot 51$ & & & $\mathrm{~N} / \mathrm{A}$ \\
\hline \multicolumn{7}{|l|}{ Policy and organizational environment } \\
\hline Menus planned by a nutritionist & 1 & $2 \cdot 9$ & $2 \cdot 17,3.80$ & 14 & 20.5 & $16.09,24.91$ \\
\hline Menus planned with student input & 31 & 63.9 & $52.11,74.59$ & 32 & $48 \cdot 0$ & $39.65,56.35$ \\
\hline Meal service (or food service) provided & 52 & 66.5 & $57.96,75.04$ & 66 & $100 \cdot 0$ & - \\
\hline \multicolumn{7}{|l|}{ Food committee } \\
\hline Presence of at least one regular food committee & 16 & 20.9 & $16 \cdot 77,25 \cdot 03$ & 35 & 52.9 & $44 \cdot 14,61.66$ \\
\hline Student involvement in food committees overall§ & 2 & $6 \cdot 6$ & $4.53,9.24$ & 28 & $62 \cdot 3$ & $49.96,73.58$ \\
\hline Menu cycle running four or more weeks & 27 & 53.2 & $43.21,63.19$ & 54 & 81.6 & $71.34,89.42$ \\
\hline \multicolumn{7}{|l|}{ Physical environment } \\
\hline \multicolumn{7}{|l|}{ Locations for eating lunch at the school } \\
\hline Presence of drinking fountains (in the room or near the entrance) or washrooms & 62 & 83.8 & $74 \cdot 37,90 \cdot 84$ & 51 & $77 \cdot 3$ & $66 \cdot 86,85 \cdot 74$ \\
\hline \multicolumn{7}{|l|}{ Food outlets near the school } \\
\hline Fast-food restaurants & 38 & $48 \cdot 2$ & $40 \cdot 50,55.90$ & 46 & 69.9 & $60 \cdot 65,79 \cdot 15$ \\
\hline Family-style restaurants & 48 & 62.2 & $53 \cdot 71,70.69$ & 50 & 75.4 & $65.03,83.99$ \\
\hline Diners (arena, mobile canteen) & 29 & 38.0 & $31 \cdot 32,44.68$ & 38 & 58.7 & $49.53,67.87$ \\
\hline Convenience stores, filling stations and pharmacies & 64 & $82 \cdot 3$ & $73.06,89.42$ & 60 & 90.9 & $81 \cdot 77,96.42$ \\
\hline Grocery stores, supermarkets & 41 & 53.3 & $45 \cdot 22,61.38$ & 44 & $66 \cdot 1$ & $56 \cdot 81,75 \cdot 39$ \\
\hline Other food outlets (e.g. dairy bars) & 27 & $35 \cdot 3$ & $29.00,41.60$ & 39 & 59.5 & $50 \cdot 29,68 \cdot 71$ \\
\hline \multicolumn{7}{|l|}{ Economic environment } \\
\hline \multirow{2}{*}{\multicolumn{7}{|c|}{ Presence of food assistance measures }} \\
\hline & & & & & & \\
\hline Breakfasts & 8 & $10 \cdot 8$ & $8.54,13.06$ & 12 & $18 \cdot 8$ & $14.85,23.29$ \\
\hline Snacks during the day (regular) & 16 & $21 \cdot 2$ & $17 \cdot 02,25 \cdot 38$ & 5 & $8 \cdot 2$ & $6.40,10 \cdot 31$ \\
\hline Tickets to buy breakfast or lunch at the cafeteria & 5 & 7.0 & $5.57,8.66$ & 28 & $42 \cdot 8$ & $34.99,50.61$ \\
\hline At the child-care service & & & & & & \\
\hline After-school snacks (regular) & 7 & $10 \cdot 7$ & $8.31,13.09$ & & & N/A \\
\hline Food provided as an emergency food measure & 40 & 57.6 & $48 \cdot 75,66 \cdot 45$ & & & $\mathrm{~N} / \mathrm{A}$ \\
\hline Sociocultural environment & & & & & & \\
\hline At school & & & & & & \\
\hline Organization of food tastings & 5 & $10 \cdot 1$ & $7.61,13.07$ & 15 & $22 \cdot 2$ & $17.48,26.92$ \\
\hline Student volunteers involved in food services & 16 & 33.0 & $25 \cdot 51,40.49$ & 44 & $66 \cdot 7$ & $57.41,75.99$ \\
\hline Sale of foods during fundraising campaigns & & & & & & \\
\hline Presence of foods or beverages of low nutritional value§ & 28 & $54 \cdot 9$ & $44.68,65.12$ & 47 & 73.9 & $63.23,82.85$ \\
\hline Organization of special events & & & & & & \\
\hline Presence of foods or beverages of low nutritional value§ & 55 & 73.0 & $63.40,81.25$ & 44 & 73.6 & $62 \cdot 67,82 \cdot 75$ \\
\hline At the child-care service & & & & & & \\
\hline Organization of food tastings & 9 & $12 \cdot 8$ & $10 \cdot 10,15 \cdot 92$ & & & $\mathrm{~N} / \mathrm{A}$ \\
\hline Presence of foods or beverages of low nutritional value§ & 1 & 0.11 & $0.05,0.21$ & & & $\mathrm{~N} / \mathrm{A}$ \\
\hline Organization of kitchen or culinary activities & 42 & $61 \cdot 0$ & $52 \cdot 01,69.99$ & & & $N / A$ \\
\hline Presence of foods or beverages of low nutritional value & 28 & $68 \cdot 2$ & $55.08,79.51$ & & & N/A \\
\hline Holidays and special occasions & & & & & & \\
\hline Presence of foods or beverages of low nutritional value§ & 60 & 94.9 & $86.23,98.93$ & & & N/A \\
\hline
\end{tabular}

$\mathrm{N} / \mathrm{A}$, not applicable.

*Schools that did not have food-related facilities were not surveyed.

†The percentages vary according to the number of questionnaires and missing data.

fBinomial proportion confidence interval.

$\S$ Among schools providing this type of product or service. 
Table 4 Correlates* of school environmental components in the primary and secondary schools surveyed, Quebec, Canada, 2008-2009

\begin{tabular}{|c|c|c|c|c|c|c|c|c|c|c|c|c|}
\hline & \multicolumn{6}{|c|}{ Primary schools } & \multicolumn{6}{|c|}{ Secondary schools } \\
\hline & \multicolumn{2}{|c|}{ Population density } & \multicolumn{2}{|c|}{ School size } & \multicolumn{2}{|l|}{ LICO } & \multicolumn{2}{|c|}{ Population density } & \multicolumn{2}{|c|}{ School size } & \multicolumn{2}{|c|}{ LICO } \\
\hline & $\begin{array}{c}\text { Test } \\
\text { value }\end{array}$ & $P$ & Test value & $P$ & $\begin{array}{c}\text { Test } \\
\text { value }\end{array}$ & $P$ & Test value & $P$ & $\begin{array}{c}\text { Test } \\
\text { value }\end{array}$ & $P$ & $\begin{array}{c}\text { Test } \\
\text { value }\end{array}$ & $P$ \\
\hline \multicolumn{13}{|l|}{ Availability of food } \\
\hline \multicolumn{13}{|l|}{ Food offerings in cafeterias } \\
\hline \multicolumn{13}{|l|}{ Index of a healthy food environment } \\
\hline Milk and soya drinks & $U=43.5$ & 0.001 & $U=81 \cdot 0$ & 0.013 & $U=67 \cdot 0$ & 0.005 & \multicolumn{2}{|c|}{ N/At } & \multicolumn{2}{|c|}{ N/A $\dagger$} & \multicolumn{2}{|l|}{ N/At } \\
\hline Vegetables and fruit & $U=94.5$ & 0.214 & $U=77 \cdot 0$ & 0.090 & $U=138.0$ & 0.907 & $U=677.0$ & 0.317 & $U=776 \cdot 0$ & 0.977 & $U=709.5$ & 0.491 \\
\hline Protein source & $U=133.0$ & 0.185 & $U=87 \cdot 0$ & 0.019 & $U=141.0$ & 0.248 & $U=60.0$ & 0.563 & $U=16 \cdot 0$ & 0.055 & $U=50 \cdot 0$ & 0.373 \\
\hline Whole-grain cereal products & $U=415 \cdot 0$ & 0.370 & $U=462.5$ & 0.821 & $U=340.5$ & 0.050 & $U=275 \cdot 0$ & 0.001 & $U=461.5$ & 0.213 & $U=317.5$ & 0.003 \\
\hline \multirow{2}{*}{\multicolumn{13}{|c|}{ Index of an unfavourable food environment }} \\
\hline & & & & & & & & & & & & \\
\hline $\begin{array}{l}\text { Beverages that are sweet or sweetened or that contain } \\
\text { caffeine }\end{array}$ & $U=119 \cdot 0$ & 0.102 & $U=142 \cdot 0$ & 0.261 & $U=126 \cdot 0$ & 0.136 & $U=699.5$ & 0.875 & $U=597 \cdot 0$ & 0.233 & $U=701.5$ & 0.890 \\
\hline $\begin{array}{l}\text { Food high in fat, sugar or sweeteners (including stuffed } \\
\text { pastry) }\end{array}$ & $U=260 \cdot 0$ & 1.000 & $U=170 \cdot 0$ & 0.085 & $U=249 \cdot 0$ & 0.832 & $U=302.5$ & 0.138 & $U=395.5$ & 0.806 & $U=333.5$ & 0.280 \\
\hline Fried foods & $U=67 \cdot 0$ & 0.051 & $U=130 \cdot 0$ & 0.747 & $U=123.5$ & 0.620 & $U=318 \cdot 0$ & 0.595 & $U=328.0$ & 0.698 & $U=307 \cdot 0$ & 0.487 \\
\hline Deli meats & $U=178.5$ & 0.431 & $U=172 \cdot 0$ & 0.355 & $U=198.0$ & 0.703 & $U=690 \cdot 0$ & 0.528 & $U=551.5$ & 0.046 & $U=724 \cdot 0$ & 0.766 \\
\hline Presence of at least one type of unfavourable food & $U=409.5$ & 0.808 & $U=316 \cdot 0$ & 0.096 & $U=403 \cdot 0$ & 0.730 & $U=100 \cdot 0$ & 0.082 & $U=179 \cdot 0$ & 0.866 & $U=165.5$ & 0.659 \\
\hline \multicolumn{13}{|c|}{ Food offerings in vending machines located near or in dining halls } \\
\hline At least $75 \%$ of contents of good nutritional value & $\mathrm{N} / \mathrm{A}$ & & $\mathrm{N} / \mathrm{A}$ & & $\mathrm{N} / \mathrm{A}$ & & $U=170 \cdot 0$ & 0.395 & $U=117 \cdot 0$ & 0.029 & $U=190 \cdot 0$ & 0.723 \\
\hline \multicolumn{13}{|l|}{ Food offerings at the child-care service } \\
\hline Number of foods/beverages with good nutritional value & $r_{\mathrm{s}}=0.283$ & 0.035 & $r_{\mathrm{s}}=0.147$ & 0.281 & $r_{\mathrm{s}}=0.427$ & 0.001 & \multirow{2}{*}{\multicolumn{2}{|c|}{ N/A }} & \multicolumn{2}{|c|}{ N/A } & \multicolumn{2}{|l|}{$\mathrm{N} / \mathrm{A}$} \\
\hline $\begin{array}{l}\text { Presence of at least one food or beverage of low nutritional } \\
\text { value }\end{array}$ & $U=345.5$ & 0.709 & $U=300 \cdot 0$ & 0.253 & $U=355.5$ & 0.838 & & & $\mathrm{~N} / \mathrm{A}$ & & N/A & \\
\hline \multicolumn{13}{|l|}{ Policy and organizational environment } \\
\hline Menus planned by a nutritionist & \multicolumn{2}{|l|}{ _- } & $U=28.5$ & 0.203 & $U=43.5$ & 0.488 & _- & & $U=327 \cdot 0$ & 0.012 & $U=388.0$ & 0.068 \\
\hline Menus planned with student input & - & & $U=406.5$ & 0.860 & $U=402 \cdot 0$ & 0.804 & - & & $U=664.5$ & 0.149 & $U=470.5$ & 0.001 \\
\hline Meal service (or food service) provided & - & & $U=583.5$ & $<0.001$ & $U=802.5$ & 0.025 & - & & NA & & NAł & \\
\hline Food committee & & & & & & & & & & & & \\
\hline Presence of at least one regular food committee & - & & $U=763.5$ & 0.817 & $U=685 \cdot 0$ & 0.357 & - & & $U=661 \cdot 0$ & 0.135 & $U=517 \cdot 0$ & 0.004 \\
\hline Student involvement in food committees overall & - & & $U=41.0$ & 0.533 & $U=28.5$ & 0.186 & - & & $U=331.0$ & 0.712 & $U=254.5$ & 0.083 \\
\hline Length of lunch period (min) & - & & $r_{\mathrm{s}}=0.033$ & 0.751 & $r_{\mathrm{s}}=0.222$ & 0.033 & - & & $r_{\mathrm{s}}=0.193$ & 0.099 & $r_{\mathrm{s}}=0.298$ & 0.010 \\
\hline Menu cycle running four or more weeks & - & & $U=462.5$ & 0.744 & $U=454.5$ & 0.659 & - & & $U=273.5$ & 0.015 & $U=271.0$ & 0.013 \\
\hline Physical environment & & & & & & & & & & & & \\
\hline Locations for eating lunch at the school & & & & & & & & & & & & \\
\hline $\begin{array}{l}\text { Presence of drinking fountains (in the room or near the } \\
\text { entrance) or washrooms }\end{array}$ & $U=312 \cdot 0$ & 0.004 & $U=416 \cdot 0$ & 0.068 & $U=520 \cdot 0$ & 0.451 & $U=399.5$ & 0.042 & $U=386 \cdot 5$ & 0.029 & $U=480 \cdot 0$ & 0.257 \\
\hline Food outlets near the school & & & & & & & & & & & & \\
\hline Fast-food restaurants & $U=974.5$ & 0.081 & - & & $U=570 \cdot 0$ & $<0.001$ & $U=518.5$ & 0.087 & - & & $U=633 \cdot 0$ & 0.595 \\
\hline Family-style restaurants & $U=1001.5$ & 0.292 & - & & $U=1011.5$ & 0.324 & $U=575 \cdot 0$ & 0.553 & - & & $U=611.5$ & 0.841 \\
\hline Diners (arena, mobile canteen) & $U=796.5$ & 0.018 & - & & $U=1025 \cdot 0$ & 0.499 & $U=505 \cdot 0$ & 0.007 & - & & $U=635.5$ & 0.150 \\
\hline Convenience stores, filling stations and pharmacies & $U=621.5$ & 0.483 & - & & $U=653.0$ & 0.681 & $U=211.0$ & 0.419 & _ & & $U=162.5$ & 0.102 \\
\hline Grocery stores, supermarkets & $U=818.5$ & 0.005 & - & & $U=1161 \cdot 0$ & 0.682 & $U=728.5$ & 0.996 & - & & $U=672.5$ & 0.568 \\
\hline Other food outlets (e.g. dairy bars) & $U=833.0$ & 0.036 & - & & $U=764.5$ & 0.009 & $U=633 \cdot 0$ & 0.163 & - & & $U=717.5$ & 0.567 \\
\hline
\end{tabular}




\begin{tabular}{|c|c|c|c|c|c|c|c|c|c|c|c|c|}
\hline & \multicolumn{6}{|c|}{ Primary schools } & \multicolumn{6}{|c|}{ Secondary schools } \\
\hline & \multicolumn{2}{|c|}{ Population density } & \multicolumn{2}{|c|}{ School size } & \multicolumn{2}{|c|}{ LICO } & \multicolumn{2}{|c|}{ Population density } & \multicolumn{2}{|c|}{ School size } & \multicolumn{2}{|c|}{ LICO } \\
\hline & $\begin{array}{c}\text { Test } \\
\text { value }\end{array}$ & $P$ & Test value & $P$ & $\begin{array}{c}\text { Test } \\
\text { value }\end{array}$ & $P$ & Test value & $P$ & $\begin{array}{c}\text { Test } \\
\text { value }\end{array}$ & $P$ & $\begin{array}{c}\text { Test } \\
\text { value }\end{array}$ & $P$ \\
\hline \multicolumn{13}{|l|}{ Economic environment } \\
\hline \multicolumn{13}{|l|}{ Presence of food assistance measures } \\
\hline Breakfasts & $U=264.5$ & 0.036 & $U=420.5$ & 0.776 & $U=264.0$ & 0.034 & $U=486.5$ & 0.918 & $U=387.5$ & 0.191 & $U=474.5$ & 0.802 \\
\hline Snacks during the day (regular) & $U=652.5$ & 0.231 & $U=671.5$ & 0.302 & $U=443.0$ & 0.002 & $U=206 \cdot 0$ & 0.373 & $U=198.0$ & 0.305 & $U=187.5$ & 0.226 \\
\hline Tickets to buy breakfast or lunch at the cafeteria & $U=319.0$ & 0.967 & $U=222 \cdot 0$ & 0.172 & $U=308 \cdot 0$ & 0.847 & $U=686 \cdot 0$ & 0.256 & $U=577.5$ & 0.030 & $U=719.5$ & 0.411 \\
\hline Number of food assistance measures & $r_{\mathrm{s}}=0.186$ & 0.065 & $r_{\mathrm{s}}=0.103$ & 0.311 & $r_{\mathrm{s}}=0.340$ & 0.001 & $r_{\mathrm{s}}=0.092$ & 0.413 & $r_{\mathrm{s}}=0.223$ & 0.046 & $r_{\mathrm{s}}=0.132$ & 0.242 \\
\hline Menu price (CAN\$) & $r_{\mathrm{s}}=0.254$ & 0.069 & $r_{\mathrm{s}}=0.117$ & 0.410 & $r_{\mathrm{s}}=0.261$ & 0.062 & $r_{\mathrm{s}}=0.200$ & 0.083 & $r_{\mathrm{s}}=0.088$ & 0.451 & $r_{\mathrm{s}}=0.261$ & 0.023 \\
\hline \multicolumn{13}{|l|}{ At the child-care service } \\
\hline After-school snacks (regular) & $U=162.5$ & 0.004 & $U=364.5$ & 0.886 & $U=151 \cdot 0$ & 0.002 & N/A & & N/A & & N/A & \\
\hline Food provided as an emergency food measure & $U=556.5$ & 0.004 & $U=806.5$ & 0.541 & $U=596 \cdot 0$ & 0.012 & $\mathrm{~N} / \mathrm{A}$ & & $\mathrm{N} / \mathrm{A}$ & & $\mathrm{N} / \mathrm{A}$ & \\
\hline \multirow{2}{*}{\multicolumn{13}{|c|}{ Sociocultural environment }} \\
\hline \multicolumn{10}{|l|}{ At school } & & & \\
\hline Organization of food tastings & _ & & $U=165.5$ & 0.505 & $U=171.0$ & 0.581 & - & & $U=480 \cdot 0$ & 0.224 & $U=520 \cdot 0$ & 0.438 \\
\hline Student volunteers involved in food services & - & & $U=262.5$ & 0.018 & $U=319 \cdot 0$ & 0.125 & - & & $U=637.0$ & 0.249 & $U=470 \cdot 0$ & 0.005 \\
\hline \multicolumn{13}{|l|}{ Sale of food during fundraising campaigns } \\
\hline $\begin{array}{l}\text { Presence of foods or beverages of low nutritional value } \\
\text { Organization of special events }\end{array}$ & $U=379.5$ & 0.092 & $U=475 \cdot 0$ & 0.695 & $U=436.5$ & 0.357 & $U=532 \cdot 0$ & 0.659 & $U=492 \cdot 0$ & 0.365 & $U=566 \cdot 0$ & 0.963 \\
\hline \multicolumn{13}{|l|}{ At the child-care service } \\
\hline Organization of food tastings & - & & $U=218.5$ & 0.014 & $U=337 \cdot 0$ & 0.356 & _ & & N/A & & N/A & \\
\hline Presence of foods or beverages of low nutritional value & $U=5.5$ & 0.406 & $U=8.0$ & 0.813 & $U=7.0$ & 0.632 & N/A & & N/A & & N/A & \\
\hline Organization of kitchen or culinary activities & - & & $U=558.5$ & 0.009 & $U=710.5$ & 0.209 & - & & N/A & & N/A & \\
\hline $\begin{array}{l}\text { Presence of foods or beverages of low nutritional value } \\
\text { Holidays and special occasions }\end{array}$ & $U=254.5$ & 0.401 & $U=230 \cdot 0$ & 0.188 & $U=173 \cdot 0$ & 0.014 & $\mathrm{~N} / \mathrm{A}$ & & N/A & & N/A & \\
\hline $\begin{array}{l}\text { Holidays and special occasions } \\
\text { Presence of foods or beverages of low nutritional value }\end{array}$ & $U=102 \cdot 5$ & 0.318 & $U=84.5$ & 0.158 & $U=114.0$ & 0.459 & N/A & & N/A & & N/A & \\
\hline
\end{tabular}

LICO, low-income cut-off; $U$, Mann-Whitney $U$ test; $r_{\mathrm{s}}$, Spearman's rho; N/A, not applicable; -, the association was not tested due to lack of relevance.

*Schools that did not have food-related facilities were not surveyed.

tThe secondary schools as a whole offered soya milk or beverages.

$\ddagger$ The secondary schools as a whole had a meal service. 
programme as well as snacks and 'emergency' foods in their child-care services were more likely to be found in densely populated areas. Finally, the schools located in densely populated areas tended to offer foods and beverages of low nutritional value at special events and during cooking activities, respectively.

\section{Secondary schools}

Low income index. Socio-economic characteristics did not play a central role in the availability of foods with high nutritional value, with one exception: schools offering refined products (e.g. white bread) instead of healthier options were situated in more deprived areas. Socio-economic characteristics were, however, associated with the establishment of a policy as well as an organizational environment favourable for a healthy diet; high level of deprivation was associated with these structural characteristics. Indeed, the schools less likely to have a regular food committee, to seek student input on menu choices and to have longer lunch periods were situated in disadvantaged areas. Menu prices were significantly lower in more disadvantaged areas. Finally, schools in disadvantaged areas were less likely to have student volunteers in their food services.

School size. In schools with a larger student population, the vending machines located near lunch areas were less likely to have contents meeting criteria for healthy foods. Larger schools tended to have their menus designed by a registered dietitian and to opt for cyclic menus running for four or more weeks. Schools with a larger student body were less likely to have drinking fountains or sinks in or near their lunch areas. Schools with a larger student population were more likely to give students tickets for buying lunch at school and to offer a variety of food assistance programmes.

Population density. Schools located in more densely populated areas had less drinking fountains or sinks in or near their lunch areas. Additionally, schools in more densely populated areas had fewer diners (food outlets) in the vicinity.

\section{Discussion}

The objective of the present study was to examine whether the school food environment was associated to LICO, school size and the population density. Bivariate analysis revealed that, in both the primary and secondary schools, the role of socio-economic and demographic characteristics varied as a function of the school food environment. In this respect, our results reveal that the schools in deprived areas provide an environment less favourable for a healthy diet.

With respect to the availability of foods with high nutritional value, we found very few primary schools with favourable food offerings (5.1\%); this was the case in $42.2 \%$ of secondary schools. Meals served in schools did not always correspond to the recommended nutritional intakes ${ }^{(27,28)}$; certain meals contained high amounts of fat, sugar or salt. By extension, studies have shown that young people eating school meals ${ }^{(29)}$ had inadequate intakes of fruit, vegetables and whole grains. Our findings are consistent with research suggesting that food and beverage companies have made only moderate progress in supporting schools in their efforts to improve the quality of food offerings, highlighting the importance of promoting food policies ${ }^{(30-32)}$.

Our study reveals that primary schools in deprived areas had a greater probability of being surrounded by fast-food restaurants and businesses such as dairy bars. Many studies corroborate these results ${ }^{(13,15,33-35)}$. The presence of food outlets enhancing accessibility of foods with low nutritional value to children ${ }^{(36)}$ can be offset with dining areas that appeal to students and entice them to stay at school for lunch ${ }^{(37)}$. Concomitantly, working with restaurants to improve the nutritional value of their meals may be a promising strategy ${ }^{(38)}$.

Large primary schools provided access to food services as well as to tasting and cooking activities through childcare services. The larger secondary schools were more likely to have menus designed by a registered dietitian, a cyclic menu of 4 weeks or longer ${ }^{(7)}$ and a broad variety of food assistance programmes. School budgets are associated with the number of pupils. As a result, larger schools have more financial latitude, enabling them to hire specialized staff. Moreover, the food services in Quebec's larger secondary schools are often managed by corporations staffed with registered dietitians who plan and revise school menus.

The presence of foods or beverages of low nutritional value during special events $(73.0 \%)$ depended on the population density; primary schools located in highdensity areas were more likely to offer foods and beverages of low nutritional quality during special events than schools located in areas with lower population density. Similar to the findings of others ${ }^{(39)}$, the majority of food items offered during class celebrations were energy-dense and of low nutrient value.

Study results also show that primary schools in disadvantaged areas were less likely to have lunchtime meal food services. This is unfortunate as school food services have been shown to offer lunches of superior nutritional quality than lunches packed at home ${ }^{(27)}$. Moreover, a study accompanied with intervention programmes showed that children living in deprived areas may have a higher prevalence of obesity ${ }^{(40)}$ and suggested that schools with food services may be particularly helpful for students from low-income families. Beyond the potential association with the size of the school, schools with a high proportion of low-income families likely have less available income for their children to purchase meals at schools. Needless to say, this provides a low business incentive for caterers to invest in such schools. 
Implementing free or low-cost meals in deprived areas could help achieve the recommended nutritional intakes.

Similar to others, our results reveal that foods of low nutritional value were more pervasive in secondary than in primary schools ${ }^{(41)}$ regardless of socio-economic status. Our results also indicate that vending machines in bigger schools offered fewer foods with good nutritional value. This finding is troubling given than the availability of low-nutrient, energy-dense foods in vending machines in or near the foodservice area has been found to be associated with a higher BMI $z$ score ${ }^{,(42)}$. We would therefore suggest paying particular attention to food quality in large schools in Quebec.

In secondary schools, a high level of disadvantage was negatively associated with the establishment of a policy and organizational environment favourable for a healthy diet. Indeed, such schools were less likely to have a regular food committee, to seek student input on menu choices or to have a long lunch period. Implementation of these strategies in secondary schools may be a low-cost approach to creating environments favourable for a healthy diet. Such interventions are already established in the UK by the Food for Life Partnership, an initiative that adopts a holistic approach to planning a favourable school food environment ${ }^{(43,44)}$. This approach includes all members of the school community, especially students, in school planning and implementing change through a School Nutrition Action Group ${ }^{(45,46)}$.

\section{Study limitations and strengths}

Given the low variability in the data for many variables, regression models including multiple socio-economic and demographic variables were not performed. Moreover, the small sample size could have limited the occurrence of significant relationships as the result of a lack of statistical power. Serving sizes were not available for all foods, which limits the accuracy of our interpretations about the food-offering quality. Lastly, while measures distinguishing urban from rural settings have been widely used in the literature, we opted for population density since it takes into account both a region's area and number of inhabitants. Despite these limitations, the present study stands as the first of its kind in Quebec. These results can be generalized to all Quebec French-language schools, with the exception of those situated in remote northern regions and on the island of Montreal. Remote schools are distinct with food offerings that differ from the rest of Quebec. Montreal Island's largest of five school boards declined to participate in the study. Our study offers an exhaustive observation of the access to foods of high nutritional value along with rich details describing the organizational and structural school factors associated with this food environment. In so doing, the study has yielded information that is essential in developing hypotheses appropriate for the Quebec context and in carrying out more targeted studies in the future.

\section{Conclusions}

In Quebec the ecological approach to health promotion has been successfully disseminated, whereby schools are beginning to implement strategies to create food environments that favour healthy choices and discourage unhealthy choices. The promotion of the Quebec food policy likely provided the framework needed for schools to implement strategies to improve food availability and food environments in schools, particularly with respect to junk food. Advancement now requires interventions to consider a number of particular school characteristics: deprived primary schools need support, particularly in implementing meal services; and school wellness committees with student participation is a low-cost technique to improve the food environment in secondary schools. Broader studies on these various characteristics or using other indicators could help level the health inequalities associated with the diets of young people.

\section{Acknowledgements}

Acknowledgements: The authors would like to thank the school principals, food-service managers and child-care managers for their time and involvement in the interviews. Special thanks go to the study co-investigators and collaborators. Financial support: This study was funded by Quebec's government and the Centre de Recherche en Prévention de l'Obésité. The funders had no role in the design, analysis or writing of this article. Conflict of interest: None. Authorship: P.M and E.R. designed and conducted the research; K.D. analysed the data; P.M. and K.D. wrote the paper; A.L. and S.B. contributed to the analyses; P.M. had primary responsibility for the final content. All authors read and approved the final manuscript. Ethics of human subject participation: The study was conducted according to the guidelines laid down in the Declaration of Helsinki and all procedures involving human subjects were approved by the research ethics committee of the Estrie Health and Social Services Centres (CER \# 08-005).

\section{References}

1. Statistique Canada (2012) Indice de masse corporelle des enfants et des jeunes canadiens, 2009 à 2011. http://www. statcan.gc.ca/pub/82-625-x/2012001/article/11712-fra.htm (accessed August 2013).

2. Wechsler H, Devereaux RS, Davis M et al. (2000) Using the school environment to promote physical activity and healthy eating. Prev Med 31, Suppl. 2, S121-S137.

3. Neumark-Sztainer D, French SA, Hannan PJ et al. (2005) School lunch and snacking patterns among high school students: associations with school food environment and policies. Int J Behav Nutr Phys Act 2, 14.

4. Glanz K, Sallis JF, Saelens BE et al. (2005) Healthy nutrition environments: concepts and measures. Am J Health Promot 19, 330-333. 
5. Briefel RR, Wilson A \& Gleason PM (2009) Consumption of low-nutrient, energy-dense foods and beverages at school, home, and other locations among school lunch participants and nonparticipants. J Am Diet Assoc 109, 2 Suppl., S79-S90.

6. Cohen DA, Scribner RA \& Farley TA (2000) A structural model of health behavior: a pragmatic approach to explain and influence health behaviors at the population level. Prev Med 30, 146-154.

7. Ministère de l'Éducation du Loisir et du Sport (2007) Pour un virage santé à l'école. Politique cadre pour une saine alimentation et un mode de vie physiquement actif. Québec: Gouvernement du Québec.

8. Santé Canada (2007) Bien manger avec le Guide alimentaire canadien. Ottawa: Santé Canada.

9. Pettigrew S, Pescud M \& Donovan RJ (2012) Stakeholder perceptions of a comprehensive school food policy in Western Australia. Health Policy 108, 100-104.

10. Mensink F, Schwinghammer SA \& Smeets A (2012) The Healthy School Canteen programme: a promising intervention to make the school food environment healthier. J Environ Public Health 2012, 415746.

11. Masse LC \& de Niet JE (2013) School nutritional capacity, resources and practices are associated with availability of food/beverage items in schools. Int J Behav Nutr Phys Act 10, 26.

12. Perlman SE, Nonas C, Lindstrom LL et al. (2012) A menu for health: changes to New York City school food, 2001 to 2011. J Sch Health 82, 484-491.

13. Davis B \& Carpenter C (2009) Proximity of fast-food restaurants to schools and adolescent obesity. Am J Public Health 99, 505-510.

14. Zenk SN \& Powell LM (2008) US secondary schools and food outlets. Health Place 14, 336-346.

15. Simon PA, Kwan D, Angelescu A et al. (2008) Proximity of fast food restaurants to schools: do neighborhood income and type of school matter? Prev Med 47, 284-288.

16. Morin P, Demers K, Gray-Donald K et al. (2012) Foods offered in Quebec school cafeterias: do they promote healthy eating habits? Results of a provincial survey. Can J Public Health 103, 249-254.

17. Simen-Kapeu A, Kuhle S \& Veugelers PJ (2010) Geographic differences in childhood overweight, physical activity, nutrition and neighbourhood facilities: implications for prevention. Can J Public Health 101, 128-132.

18. Hollands S, Campbell MK, Gilliland J et al. (2013) A spatial analysis of the association between restaurant density and BMI in Canadian adults. Prev Med 57, 258-264.

19. Stark JH, Neckerman K, Lovasi GS et al. (2013) Neighbourhood food environments and body mass index among New York City adults. J Epidemiol Community Health 67, 736-742.

20. Ministère de la Santé et des Services sociaux (2012) Pour une vision commune des environnements favorables à la saine alimentation, à un mode de vie physiquement actif et à la prévention des problèmes reliés au poids. Québec: Gouvernement du Québec.

21. Oldenburg B, Sallis JF, Harris D et al. (2002) Checklist of health promotion environments at worksites (CHEW): development and measurement characteristics. Am J Health Promot 16, 288-299.

22. Côté G, Déry V \& Vanier L (2002) État de situation de l'environnement alimentaire dans les écoles secondaires publiques de la région de Montréal-Centre. Montréal: Régie régionale de la santé et des services sociaux de MontréalCentre.

23. Beauchesne-Rondeau E \& Chaumette P (2004) Situation environnementale de la nutrition dans les écoles de la région de la Capitale Nationale. Québec: Agence de développement des réseaux locaux de services de santé et de services sociaux de la Capitale nationale.
24. Affaire municipales, Régions et Occupation du territoire (2010) Répertoire des municipalités. http://www.mamrot.gouv.qc.ca/ repertoire-des-municipalites/ (accessed February 2012).

25. Ministère de l'Éducation, du Loisir et du Sport (2011) Indices de défavorisation par école - 2008-2009. http://www.mels. gouv.qc.ca/fileadmin/site_web/documents/PSG/statistiques_ info_decisionnelle/Ensemble_Indices_08-09.pdf (accessed December 2014).

26. StatistiqueCanada (2010) Les seuils de faible revenu. http:// www.statcan.gc.ca/pub/75f0002m/2010005/C-sfr-fra.htm (accessed July 2012).

27. Taylor JP, Hernandez KJ, Caiger JM et al. (2012) Nutritional quality of children's school lunches: differences according to food source. Public Health Nutr 15, 2259-2264.

28. Crepinsek MK, Gordon AR, McKinney PM et al. (2009) Meals offered and served in US public schools: do they meet nutrient standards? J Am Diet Assoc 109, 2 Suppl., S31-S43.

29. Turner L \& Chaloupka FJ (2012) Slow progress in changing the school food environment: nationally representative results from public and private elementary schools. J Acad Nutr Diet 112, 1380-1389.

30. Story M, Nanney MS \& Schwartz MB (2009) Schools and obesity prevention: creating school environments and policies to promote healthy eating and physical activity. Milbank Q 87, 71-100.

31. Kraak VI, Story M, Wartella EA et al. (2011) Industry progress to market a healthful diet to American children and adolescents. Am J Prev Med 41, 322-333.

32. Pica LA, Traoré I, Bernèche F et al. (2012) L'Enquête québécoise sur la santé des jeunes du secondaire 2010-2011. Le visage des jeunes d'aujourd'bui: leur santé physique et leurs habitudes de vie, Tome 1. Québec: Institut de la statistique du Québec.

33. Cummins SCJ, McKay L \& MacIntyre S (2005) McDonald's restaurants and neighborhood deprivation in Scotland and England. Am J Prev Med 29, 308-310.

34. Robitaille E, Bergeron P \& Lasnier B (2009) Analyse géographique de l'accessibilité des restaurants-minute et des dépanneurs autour des écoles publiques québécoises. Québec: Institut national de santé publique du Québec.

35. Seliske LM, Pickett W, Boyce WF et al. (2009) Density and type of food retailers surrounding Canadian schools: variations across socioeconomic status. Health Place $\mathbf{1 5}$, 903-907.

36. Austin SB, Melly SJ, Sanchez BN et al. (2005) Clustering of fast-food restaurants around schools: a novel application of spatial statistics to the study of food environments. $\mathrm{Am} \mathrm{J}$ Public Health 95, 1575-1581.

37. Beaulieu D \& Godin G (2012) Staying in school for lunch instead of eating in fast-food restaurants: results of a quasiexperimental study among high-school students. Public Health Nutr 15, 2310-2319.

38. Sugarman SD \& Sandman N (2008) Using performancebased regulation to reduce childhood obesity. Aust $N Z$ Health Policy 5, 26.

39. Isoldi KK \& Dalton S (2012) Calories in the classroom: celebration foods offered and consumed during classroom parties at an elementary school in a low-income, urban community. Child Obes 8, 378-383.

40. Li J \& Hooker NH (2010) Childhood obesity and schools: evidence from the national survey of children's health. $J$ Sch Health 80, 96-103.

41. Finkelstein DM, Hill EL \& Whitaker RC (2008) School food environments and policies in US public schools. Pediatrics 122, e $251-\mathrm{e} 259$.

42. Fox MK, Dodd AH, Wilson A et al. (2009) Association between school food environment and practices and body mass index of US public school children. I Am Diet Assoc 109, 2 Suppl., S108-S117. 
43. Kimberlee R, Jones M, Morley A et al. (2013) Whole school food programmes and the kitchen environment. Br Food J 115, 756-768.

44. Jones M, Dailami N, Weitkamp E et al. (2012) Food sustainability education as a route to healthier eating: evaluation of a multi-component school programme in English primary schools. Health Educ Res 27, 448-458.
45. Passmore S \& Harris G (2005) School Nutrition Action Groups and their effect upon secondary school-aged pupils' food choices. Nutr Bull 30, 364-369.

46. Orme J, Jones M, Salmon D et al. (2013) A process evaluation of student participation in a whole school food programme. Health Educ 113, 168-182.

\section{Appendix}

\section{Beverages and foods favourable or unfavourable for a bealthy diet provided in vending machines and at the child-care service ${ }^{\star}$}

Beverages and foods favourable for a healthy diet

\section{Beverages}

Tomato or vegetable juice

$100 \%$ pure fruit juice (or beverages based on same)

Plain or carbonated water; herbal tea

Plain milk

Flavoured milk (less than $30 \mathrm{~g}$ of sugar per $250 \mathrm{ml}$ )

Yoghurt drinks

Enriched soya beverages

Foods

Dried, fresh or canned fruit

Fruit-based desserts without cereal products (e.g. baked apple)

Cooked vegetables (including potatoes)

Raw vegetables

Vegetable salad (including potatoes)

Bean salad/tofu

Whole-grain salad

Sandwich on whole-grain bread/with protein

Whole-grain breakfast cereals

Whole-grain crackers

Whole-grain bread

Whole-grain cereal products (e.g. rice)

Yoghurt/fresh cheese

Ice milk, frozen yoghurt

Other milk-based desserts

Cheese

Meat and substitutes (except deli meats)

Chocolate with $70 \%$ or more cocoa

Nuts (with or without dried fruit)

Legume-based snack foods

Other dishes with protein but without cold cuts
Beverages and foods unfavourable for a healthy diet

Beverages

Flavoured milk ( $30 \mathrm{~g}$ or more of sugar per $250 \mathrm{ml}$ )

Soft drinks (regular or diet)

Other sugar-free beverages without sweetener

Other beverages with sugar (e.g. punch)

Coffee, tea (hot)

Hot chocolate

Energy drink

Foods

Fried or pre-fried foods

Stuffed pastry

Deli meats

Croissants (with or without deli meats)

Regular dehydrated noodles

Vegetable- or grain-based snack foods high in fat (e.g. chips)

Cream-based supplements

Sweets (frozen, candy, hard candy, gum, chocolate with less

than $70 \%$ cocoa, nuts or dried fruit with sugary coating)

Sweet spreads

Desserts with sugar or sweetener, without cereal products (e.g

JELL-O ${ }^{\circledR}$ with sugar or sweetener)

Red or white packaged products $†$

*Bouillon-based soups, cream soups, refined grain products, grain-based desserts/snacks, as well as chips, snack foods, and oven-baked dehydrated noodles were not considered given the ambiguity associated with their nutritional quality.

†Products to be eaten only occasionally or to avoid according to the Quebec government's framework policy on a healthy diet and physically active lifestyle. 